\title{
to \\ Scaling The Psychological Variables That Affect Performance of Athletes By Means of Pairwise Comparison Method
}

\author{
Abdulaziz KULAK* Hüseyin SELVİ **
}

\begin{abstract}
Athletes constantly train for condiditon and success. However, training is not enough to achieve the desired success. Today sports training where scientific point of view is prioritized is an important element for athletes. Studies show that sportive success depends on the development of physical skills as well as psychological condition of the athletes. The review of literature has shown that there are many studies investigating the variables that affect the performance of athletes in a positive or negative way. However, there seems to be no study in the literature in which the psychological variables that considered to affect athlete performance and scaled variables in terms of their importance levels. Therefore, the aim of this study is to determine the variables that affect the performance of the players and to scale these variables by the pairwise comparison method according to their level of importance.The study group consists of Şanliurfa Spor football players and coaches, and amateur football players and coaches in Sanliurfa. Data were collected from a total of 147 participants. Pairwise comparison method and fifth case equation is used in data analysis. Findings showed that the most important variable that affecting the athletes performance is 'self confidence' and the least important variable is 'anxiety'. According to findings, it is thought and suggested that such psychological variables as self-confidence, goal setting, motivation and attention should be included in exercises in order to enhance the performance of athletes. It is also recommended to conduct similar studies for different sports branches and different levels.
\end{abstract}

Keywords: Psychological variables in football, Pairwise comparison method, Scaling

\section{Sporcu Performansını Etkileyen Psikolojik Değişkenlerin Önem Düzeylerine Göre İkili Karşılaştırmalar Yöntemiyle Ölçeklenmesi}

$\ddot{O} \mathbf{z}$

Sporcular, kondisyon ve başarı için sürekli antrenman yapmaktadırlar. Ancak istenilen başarıya ulaşmak için yalnızca antrenman yapmak yeterli değildir. Günümüzde bilimsel anlayışı ön planda tutulduğu sportif antrenmanlar; sporcu gelişiminin önemli bir unsurudur. Yapılan çalışmalar, sportif başarının sporcunun fiziksel becerilerin geliştirilmesinin yanında psikolojik açıdan da geliştirilmesine bağlı olduğunu göstermektedir. Yapılan alanyazın incelemesi sporcu performansını olumlu ya da olumsuz etkileyen değişkenleri inceleyen pek çok çalışma yapıldığını göstermiştir. Ancak alanyazında özellikle sporcu performansını etkilediği düşünülen psikolojik değişkenlerin saptanması ve önem düzeylerine göre ölçeklenmesiyle ilgili herhangi bir çalışmaya rastlanmamıştır. Bu nedenle bu çalışmada; sporcu performansını etkilediği düşünülen psikolojik değiş̧kenlerin saptanması, ölçeklenmesi ve eşit aralıklı bir ölçek üzerine yerleşiminin sağlanması amaçlanmaktadır. Araştırmanın çalışma grubunu Şanlıurfaspor futbolcu ve antrenörleri ile Şanlıurfa'daki amatör futbolcu ve antrenörler oluşturmaktadır. Çalışma kapsamında 147 kişiden veri toplanmıştır. Çalı̧̧ma grubu üzerinden elde edilen verilerin ölçeklenmesi, tam veri matrisi üzerinden beşinci hal denklemiyle gerçekleştirilmiştir. Elde edilen bulgular sporcuların, performansların etkilediğini düşündükleri en önemli değişkenin 'özgüven' (1.38) olduğunu, en önemsiz değişkenin ise 'kaygı' (0.00) olduğu göstermiştir. Elde edilen bulgular doğrultusunda sporcuların performanslarını artırmak amacıyla, yapılan fiziksel antrenman programlarına; psikolojik değişkenlerden özgüven, hedef belirleme, motivasyon ve dikkat çalışmalarına yönelik egzersizlerin eklenmesi önerilmektedir. Benzer çalışmaların farklı spor branşları ve farklı profesyonellik seviyeleri için de tekrarlanması önerilmektedir.

Anahtar Kelimeler: Sporda psikolojik değişkenler, İkili karşılaştırmalar yöntemi, Ölçekleme

\footnotetext{
* Harran Üniversity, Physical Education and Sports School, Şanliurfa-Turkey, e-mail: azizkulak@hotmail.com Orcid Id: https://orcid.org/0000-0003-4054-3336

**Mersin Üniversity, Faculty of Medicine, Department of Medical Education, Mersin-Turkey, e-mail: hsyn_selvi@yahoo.com.tr Orcid Id: https://orcid.org/0000-0002-3513-0003 


\section{INTRODUCTION}

Athletes constantly train for condiditon and success. However, training is not enough to achieve the desired success.

Today sports training where scientific point of view is prioritized, is an important element for athletes. Studies show that sportive success depends on the development of physical skills as well as psychological condition of the athletes (Aktop, 2008; Parapavessis et al., 1992; Kose, 2018; Uzun et al., 2017).

For this reason, athletes need to make psychological training as well as condition training in order to use their performance at the highest level.

In this context, it is important for the coaches to include activies in their programs for the development of psychological variables such as motivation, anxiety, self-confidence and attention (Başer, 1998). It has been reported in studies that there is a significant relationship between the performances of the athletes and psychological variables such as motivation, anxiety, self-confidence and attention.

The study conducted by Parevesis et al. (1992) reports that feedback on psychological variables resulted in a significant decrease in the anxiety of the athletes, and this situation significantly increase performance and self-confidence.

Similarly, another study by Terry and Mayer (1998) showed that trainings for psychological variables are very effective in reducing competition stress and anxiety.

In the study conducted by Aktop (2008), it was found that controlling the psychological variables such as motivation, anxiety and self-confidence increases athletes' performance.

The review of literature has shown that there are many studies investigating the variables that affect the performance of athletes in a positive or negative way.

However, there seems to be no study in the literature in which the psychological variables that considered to affect athlete performance and scaled variables in terms of their importance levels.

Therefore, the aim of this study is to determine the variables that affect the performance of the players and to scale these variables by the pairwise comparison method according to their level of importance.

The findings of this study are considered important for coaches and footballers as they are expected to raise awareness in terms of the psychological variables affecting performance. The study is also expected to contribute to the athletes success directly and indirectly by offering new trainings for important / primary psychological variables to sports training programs.

\section{METHOD}

The aim of this study is to scale the psychological variables that affect footballer performance. Therefore, the study can be considered as a descriptive study. Ethics committee approval for research was obtained from Mersin University Ethics Committee of Social Sciences.

The pairwise comparison method developed by Thurstone (1927) in order to scale attitudes. This method can be adapted to many different situations in which the variables can be compared in pairs. 
In scaling with pairwise comparisons, the axis, where the magnitudes of the stimuli are perceived by the judges, are defined as the psychological dimension, and the axis which are arranged according to their physical size is characterized as the physical dimension, and the scaling attempts to reveal the relationship between these two dimensions (Torgerson, 1958).

\section{Research Group/ Sample}

The population of the study consists of the professional and amateur football players and coaches of Şanliurfaspor football team. Data were collected from a total of 147 participants.

\section{Data Collection Tools}

In the preparation stage of the measurement tool, the literature was firstly reviewed and the variables which were considered to affect the performances of the footballers were determined. Moreover, the coaches and the footballers were asked to respond to the question "What are the psychological variables that affect footballers' performance".

Based on the reviewed literature and coach-footballer opinions, nine of the variables (motivation, self-confidence, goal setting, intelligence, attention, stress, anxiety, learning, concentration), which are considered to be the most frequently mentioned were determined, and the measurement tool was prepared accordingly to compare these variables in pairs. The data collection tool contains all the pairwise combinations of nine variables.

\section{Data Analysis}

Data analysis was conducted through pairwise comparision in the form of full ranking over the complete data matrix with fifth degree equation.

With this purpose;

Preference frequencies for variable pairs were obtained and frequencies matrix $(\mathrm{F})$ was formed by placing these frequencies on a $9 X 9$ matrix.

In the next step, the values of matrix (p) were calculated by dividing the values in each cell of the frequency matrix by the total number of people.

Next, the unit normal deviation values matrix (Z) was obtained by determining the unit normal deviation values corresponding to the cell values in the proportions matrix.

The average values of each column in the $\mathrm{Z}$ matrix were then obtained and the scale values of the variables were identified.

Finally the smallest scale value was fixed to be zero and this value was added to other scale values and variables were placed on an equally spaced scale starting at point 0 .

The calculation of the scale values by pairwise comparisons method requires the internal consistency of the measurement assumptions and scale values. For this reason, the scale values obtained from the data were converted back to unit normal deviations ( $\mathrm{Z}$ ) matrix and the theoretical ratio matrix was obtained from this matrix to investigate the difference between the theoretical ratios and the observed ratios. At this stage, the mean-error value was calculated by means of the difference between the theoretical ratios and the observed rates, and the significance of this value was tested with chi-square statistics at the related degree of freedom (Turgut \& Baykul, 1992). 
Kulak A., Selvi H. (2019). Scaling The Psychological Variables That Affect Performance of Athletes By Means of Pairwise Comparison Method. International Journal of Recreation and Sport Science, 3 (1); 1624.

\section{FINDINGS}

Mean-error values were calculated in order to determine the computability of the scale values and found to be 0.018874 . The chi-square value for the mean error values was found to be 44.177 . It was determined that this value did not exceed the table value of 0.05 and 36 degree-offreedom $(\chi 2=44.177<\chi 2$ Table $(0.05 ; 36)$ $=50.998)$. These values indicate that the internal consistency was ensured in terms of the measurement assumptions and the scale values.

Table 1. Frequencies Matrix Obtained from Athletes $\mathrm{F}(\mathrm{n}(\mathrm{Sj}>\mathrm{Sk}))^{*}$

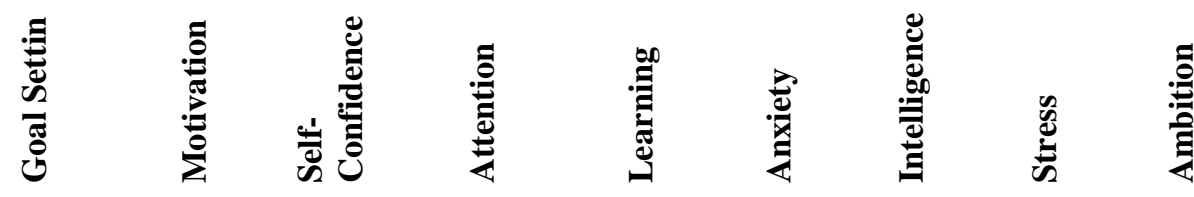

\begin{tabular}{lccccccccc}
\hline Goal Setting & --- & 63 & 89 & 49 & 68 & 19 & 88 & 24 & 68 \\
\hline Motivation & 84 & --- & 92 & 57 & 75 & 16 & 86 & 17 & 52 \\
\hline Self-Confidence & 58 & 55 & --- & 41 & 35 & 20 & 67 & 13 & 42 \\
\hline Attention & 98 & 90 & 106 & --- & 81 & 19 & 106 & 23 & 64 \\
\hline Learning & 79 & 72 & 112 & 66 & --- & 25 & 93 & 25 & 49 \\
\hline Anxiety & 128 & 131 & 127 & 128 & 122 & --- & 125 & 70 & 121 \\
\hline Intelligence & 59 & 61 & 80 & 41 & 54 & 22 & --- & 30 & 41 \\
\hline Stress & 123 & 130 & 134 & 124 & 122 & 77 & 117 & --- & 121 \\
\hline Ambition & 79 & 95 & 105 & 83 & 98 & 26 & 106 & 26 & --- \\
\hline Total & 708 & 697 & 845 & 589 & 655 & 224 & 788 & 228 & 558 \\
\hline
\end{tabular}

$* F(n(S j>S k))$ : Shows the ratio of the number of individuals who expressed that variable $\mathrm{j}$ is more important than the variable $\mathrm{k}$.

Table 2. Proportions Matrix Obtained from Athletes $(\mathrm{n}(\mathrm{Sj}>\mathrm{Sk} / \mathrm{N}))^{*}$

\begin{tabular}{lllllllllll}
\hline & & & & & & & & & & \\
& & &
\end{tabular}


Kulak A., Selvi H. (2019). Scaling The Psychological Variables That Affect Performance of Athletes By Means of Pairwise Comparison Method. International Journal of Recreation and Sport Science, 3 (1); 1624.

Table 3. Normal Deviations Matrix of Units Obtained from Athletes Z

\begin{tabular}{|c|c|c|c|c|c|c|c|c|c|}
\hline & 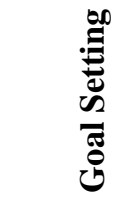 & . & ن & & & 窇 & 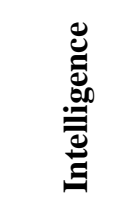 & 崖 & 苞 \\
\hline Goal Setting & 0,0000 & $-0,181$ & 0,266 & $-0,432$ & $-0,095$ & $-1,131$ & 0,248 & $-0,982$ & 0,095 \\
\hline Motivation & 0,179 & 0,0000 & 0,319 & $-0,287$ & 0,025 & $-1,237$ & 0,215 & $-1,200$ & $-0,377$ \\
\hline Self-Confidence & $-0,269$ & $-0,321$ & 0,0000 & $-0,589$ & $-0,713$ & $-1,098$ & $-0,113$ & $-1,353$ & $-0,568$ \\
\hline Attention & 0,429 & 0,285 & 0,586 & 0,0000 & 0,128 & $-1,131$ & 0,586 & $-1,036$ & $-0,164$ \\
\hline Learning & 0,093 & $-0,028$ & 0,710 & $-0,128$ & 0,0000 & $-0,954$ & 0,337 & $-0,954$ & $-0,432$ \\
\hline Anxiety & 1,126 & 1,232 & 1,094 & 1,126 & 0,950 & 0,0000 & 1,036 & $-0,060$ & 0,927 \\
\hline Intelligence & $-0,251$ & $-0,215$ & 0,111 & $-0,589$ & $-0,340$ & $-1,041$ & 0,0000 & $-0,842$ & $-0,589$ \\
\hline Stress & 0,978 & 1,195 & 1,347 & 1,007 & 0,950 & 0,058 & 0,824 & 0,0000 & 0,927 \\
\hline Ambition & 0,093 & 0,375 & 0,565 & 0,161 & 0,419 & $-0,931$ & 0,586 & $-0,931$ & 0,0000 \\
\hline$\Sigma$ zjk & 2,378 & 2,342 & 4,998 & 0,269 & 1,324 & $-7,465$ & 3,719 & $-7,358$ & $-0,181$ \\
\hline Zjort. & 0,264 & 0,260 & 0,555 & 0,030 & 0,147 & $-0,829$ & 0,413 & $-0,818$ & $-0,020$ \\
\hline Sj & 1,093 & 1,089 & 1,384 & 0,859 & 0,976 & 0,000 & 1,242 & 0,011 & 0,809 \\
\hline
\end{tabular}

Table 4. Scale values obtained within the scope of the research

\begin{tabular}{lcc}
\hline Variables & $\begin{array}{c}\text { Scale Value } \\
(\mathrm{Sj})\end{array}$ & $\begin{array}{c}\text { Order of } \\
\text { Importance }\end{array}$ \\
\hline Goal Setting & 1,093 & $\mathbf{3}$ \\
\hline Motivation & 1,089 & $\mathbf{4}$ \\
\hline Self-Confidence & 1,384 & $\mathbf{1}$ \\
\hline Attention & 0,859 & $\mathbf{6}$ \\
\hline Learning & 0,976 & $\mathbf{5}$ \\
\hline Anxiety & 0 & $\mathbf{9}$ \\
\hline Intelligence & 1,242 & $\mathbf{2}$ \\
\hline Stress & 0,011 & $\mathbf{8}$ \\
\hline Ambition & 0,809 & $\mathbf{7}$ \\
\hline
\end{tabular}

Table 1 shows the preference frequencies (sj> sk) of the athletes, Table 2 shows the matrix of proportions (p) obtained by dividing the values in each cell of the frequency matrix by the total number of participants, Table 3 presents the unit normal deviation values corresponding to the cell values in the proportions matrix and Table 4 shows the scale values of the 
investigated variables and their ranking according to their levels of significance.
The ranking of the examined variables based on scale values is presented in Figure 1 on a number line.

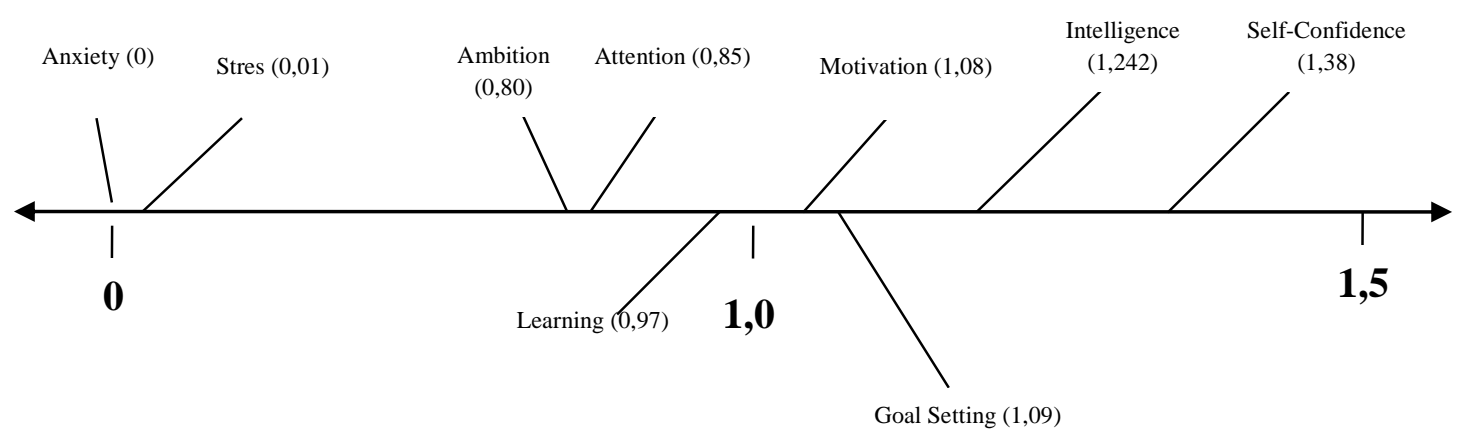

Figure 1. Ranking of Scale Values Obtained from Athletes

The findings reveal that 'self-confidence' (1.38) was the most important variable that the athletes thought affected their performance, and 'anxiety' $(0.00)$ was the least significant variable. The other variables, in order of importance, are 'stress' (0.01), 'ambition' (0.80), 'attention' (0.85), 'learning' (0.97), 'motivation' (1.08), 'goal setting' (1.09) and 'intelligence' (1.242).

\section{DISCUSSION AND CONCLUSION}

In this study, nine variables, which are thought to affect the performances of football players, were scaled through pairwise comparisions method based on their level of importance considering the opinions of the athletes and coaches.

The findings showed that four most important variables were self-confidence, intelligence, goal setting and motivation. It is known that it is difficult to reach the peak performance in football training as it is based on the development of technical, tactical and motoric properties as a basis.
In this vein, this can be the reason why coaches and footballers perceive the variables of self-confidence, intelligence, goal setting and motivation among the most important variables for a skill and performance-oriented football game. The findings are in line with those of the study by Campos (2015). Campos (2015) investigated the variables affecting football performance in a study on the footballers playing at Spain minor league. The results of the study showed that there was a significant relationship between self-confidence and anxiety variables in terms of athlete performance.

Similarly, Zuber and Zibung (2015) highlighted the importance of motivation in their study on the development of skills in young football players, and stated that high levels of motivation for success had a positive effect on performance.

Orosz and Mezo (2015) stated that the development of psychological factors (concentration, anxiety, self-confidence, 
coping and social skills) improve performance in football.

On the other hand, the least significant variable was found to be anxiety. Rodrigo et al. (1990) found a negative correlation between performance and anxiety in footballers' self-confidence and anxiety.

Moreover, Hernandez et al. (2008), in their study on athletes, reports that selfconfidence and anxiety affect performance.

The goal setting variable, as another variable investigated within the scope of the study, was considered important by the participants. Toros et al. (2010) in their study on footballers have reported similar findings. They found that the goal setting trainings as a part of football training had a positive effect on penalty shots by increasing the performance significantly, thus, they indicated that not only physical, but also psychological factors are important to increase sport performance.

In their study on 13-15 year-old football players, Karabulut et al. (2013) stated that the father's level of education increases the level of anxiety in young football players.

In this study conducted on coaches and footballers, the reason why the anxiety variable was ranked the last in terms of importance level might be because of such factors as coaches' low level of education, professional experience and incompetency.

On the other hand, variables of stress, ambition, attention, and learning were considered to be less important than the other variables. However, it is not proper to state that these variables do not have a significant contribution to football players' performance. Keeping in mind that the aim of this study is to scale the variables that are thought to affect the performances of the players according to their importance levels, it is a proper to indicate that these variables were perceived as less important than the other variables. In the related literature, there are a number of studies showing that variables such as self-confidence, intelligence, goal setting, motivation, learning, attention, ambition, stress and anxiety have a significant effect on the performance levels of athletes (Bouer, 1993; Gould, 1993; Konter, 2002; Pargman, 1998; Burton 2002).

\section{RECOMMENDATIONS}

Findings obtained from this research showed that the most important of the variables that are considered to affect the performance of athletes' performance are 'self-confidence', 'stress', 'ambition', 'attention', 'learning', 'motivation', 'goal setting', 'intelligence' and ' anxiety ' in order of importance.

In this context, it is recommended that these variables should be taken into consideration in athlete training, and activities to develop individuals in terms of psychological variables should be included in training programs.

Within the scope of this study, the opinions of professional and amateur coaches / athletes were not analyzed seperately due to the assumption that sufficient number of participants to ensure the internal consistency of the measurement assumptions and scale values may not be reached. The obtained findings thus reflect the views and opinions of all participants. However, the analysis of these psychological variables 
from seperate perspectives of professionals and amateurs, coaches and athletes will contribute significantly to the literature. It is also recommended to conduct similar studies for different sports branches and different levels

\section{REFERENCES}

Aktop, A. (2008). Biyolojik geri bildirimle zihinsel antrenman yönteminin dart performansina etkisinin incelenmesi. Yayınlanmamış Doktora Tezi, Akdeniz Üniversitesi.

Başer, E. (1998). Uygulamall spor psikolojisi. Bağırgan Yayınevi.

Bouer, G. (1993). Soccer techniques, tactics and teamwork. New York: Sterling Publishing.

Burton, D. (2002). The jekyle hyde nature of goals: revisiting and updating goal setting in sport. Advances in Sport Psychology (Edt): Human Kinetics Books.

Campos, G. (2015). Correlational study of psychological variables selfconfidence and anxiety. Motriz, Rio Claro, 21: 352-360.

Gould, D. (1993). Goal setting for pesk performance. In Willias, J. M. (Ed) Applied Spor Psychology: Personal Growth to Peak Performance.

Hernandez, R., Olmedilla, A., \& Ortega, E. (2008). Anxiety and self confidence of young judokas in competitive situations of high pressure. Analise Psicologica, 4(26): 689-696.
Karabulut, E., Atasoy, M., Kaya, K., Karabulut A., (2013). 13-15 yaş arası erkek futbolcuların durumluk ve sürekli kaygı düzeylerinin farklı değişkenler bakımından incelenmesi. Ahi Evran Üniversitesi Kırşehir Eğitim Fakültesi Dergisi (KEFAD). (14)1: 243-253.

Konter, E. (2002). Profesyonel futbolda baz〉 değişkenlere gore psikolojik becerilerin araştırılması Yayınlanmamış Doktora Tezi, Çukurova Üniversitesi, Sosyal Bilimler Enstitüsü.

Köse, B. (2018). Does Motivational Music Influence Maximal Bench Press Strength and Strength Endurance?.Asian Journal of Education and Training, 4(3), 197200.

Orosz, R., Mezo, F. (2015). Psychological factors in the development of football -talent from the perspective of an integrative sport- talent model Journal Fort The Education Of Gifted Young Scientists 3(1) 58-76.

Pargman, D. (1998). Understanding sport behavior. New Jersey: Prantice Hall.

Prapavessis, H. Grove, JR., Mcnair, PJ., Cable, NT. (1992). Self regulation training, state anxiety, and sport performance; a psychological case study. The Sport Psychologist. 6.213-229.

Rodrigo, G., Lusiardo, M., \& Pereira, G. (1990). Relationship between anxiety and performance in soccer players. International Journal of Sport Psychology. 21: 112-120. 
Terry, P. C., Mayer, J. L. (1998). Effectiveness of a mental training program for novice scuba divers. Journal Of Applied Sport Psychology. 10 (2): 251-267.

Thurstone LL (1927). A law of comparative judgment. Psychological Review; 34: 273-286.

Torgerson, W.S. (1958). Theory and methods of scaling. NewYork: John Wiley and Sons, Inc.

Toros T, Bayansalduz, M, Duvan A. (2010). Sporda hedef belirlemenin penaltı atışları üzerine etkisinin araştırılması. Niğde Üniversitesi Beden Eğitimi Ve Spor Bilimleri Dergisi.

Turgut M.F., Baykul Y. (1992). Ölçekleme teknikleri: Ankara: ÖSYM Yayınları.

Uzun, M., Özlü, K., Dalbudak, İ., Köse, B., Gürkan A. C., (2017). A review study on the antropometric characteristics and some physiological parameters of some judoists. The Journal of Academic Social Science (5) 60, 253-282.

Zuber, C., Zibung, M., (2015). Motivational patterns as an instrument for predicting success in promising young football players. Journal of Sports Sclences. 